\title{
ANALISIS BRAND AWARENESS DAN PENGARUHNYA TERHADAP BUYING DECISION MOBIL TOYOTA CALYA DI MAKASSAR
}

\author{
Syahriah Sari ${ }^{1}$, Syamsuddin ${ }^{2}$, Syahrul $^{3}$ \\ 1,2 Dosen Jurusan Admiistrasi Niaga, Politeknik Negeri Ujung Pandang \\ ${ }^{3}$ Mahasiswa Jurusan Admiistrasi Niaga, Politeknik Negeri Ujung Pandang \\ Syahriahsari@poliupg.ac.id
}

\begin{abstract}
ABSTRAK
Penelitian ini dilakukan pada PT Hadji Kalla di Makassar. Permasalahan yang terjadi pada penelitian ini yaitu turunnya pejualan mobil toyota calya selama rentang waktu 2017-2019. Penelitian ini bertujuan untuk mengetahui: brand awareness, buying decision dan pengaruh brand awareness terhadap buying decision Toyota Calya di Makassar. Hasil penelitian menunjukkan bahwa Brand awareness sangat baik dan keputusan pembelian sangat baik. Brand awareness berpengaruh positif dan signifikan terhadap buying decision Toyota Calya di Makassar.
\end{abstract}

Kata kunci: Brand awareness dan buying decision

\begin{abstract}
This research was conducted at PT Hadji Kalla in Makassar. The problem that occurred in this research is the decline of sales of Toyota Calya cars during the period 2017-2019. This study aims to find out: brand awareness, buying decision and the effect of brand awareness on buying decision of Toyota Calya cars in Makassar. The research showed that Brand awareness is excellent and purchasing decisions are excellent. Brand awareness has a positive and significant effect on buying decision of Toyota Calya cars in Makassar.
\end{abstract}

Keywords: Brand awareness and buying decision

\section{PENDAHULUAN}

Toyota Calya dengan komposisi angkut 7 penumpang merupakan salah satu merek kendaraan roda empat pada kelas Low Cost Green Car (LCGC) diperkenalkan secara resmi di Indonesia pada acara Gaikindo Indonesia Internasional Auto Show (GIIAS) 2016 pada 11 Agustus 2016. Awalnya Toyota Calya mendapat respon sangat baik di masyarakat karena dinilai murah. pada acara GIIAS 2016 mobil tersebut berhasil memuncaki angka kontribusi Surat Pemesanan Kendaraan (SPK) dengan penjualan mencapai 1.771 unit. Sementara untuk penjualan sepanjang Juli-Desember 201647.287 unit dengan rata-rata penjualan 7.881 unit (kompas.com). Namun dari tahun ke tahun penjualannya mengalami penurunan sementara pesaing utamanya adalah Honda Brio dan Daihatsu Sigra justru mengalami peningkatan sebagaimana pada gambar berikut ini. 


\section{Gambar 1}

Penjualan Tiga Mobil LCGC Terlaris Se-Indonesia Tahun 2017-2019

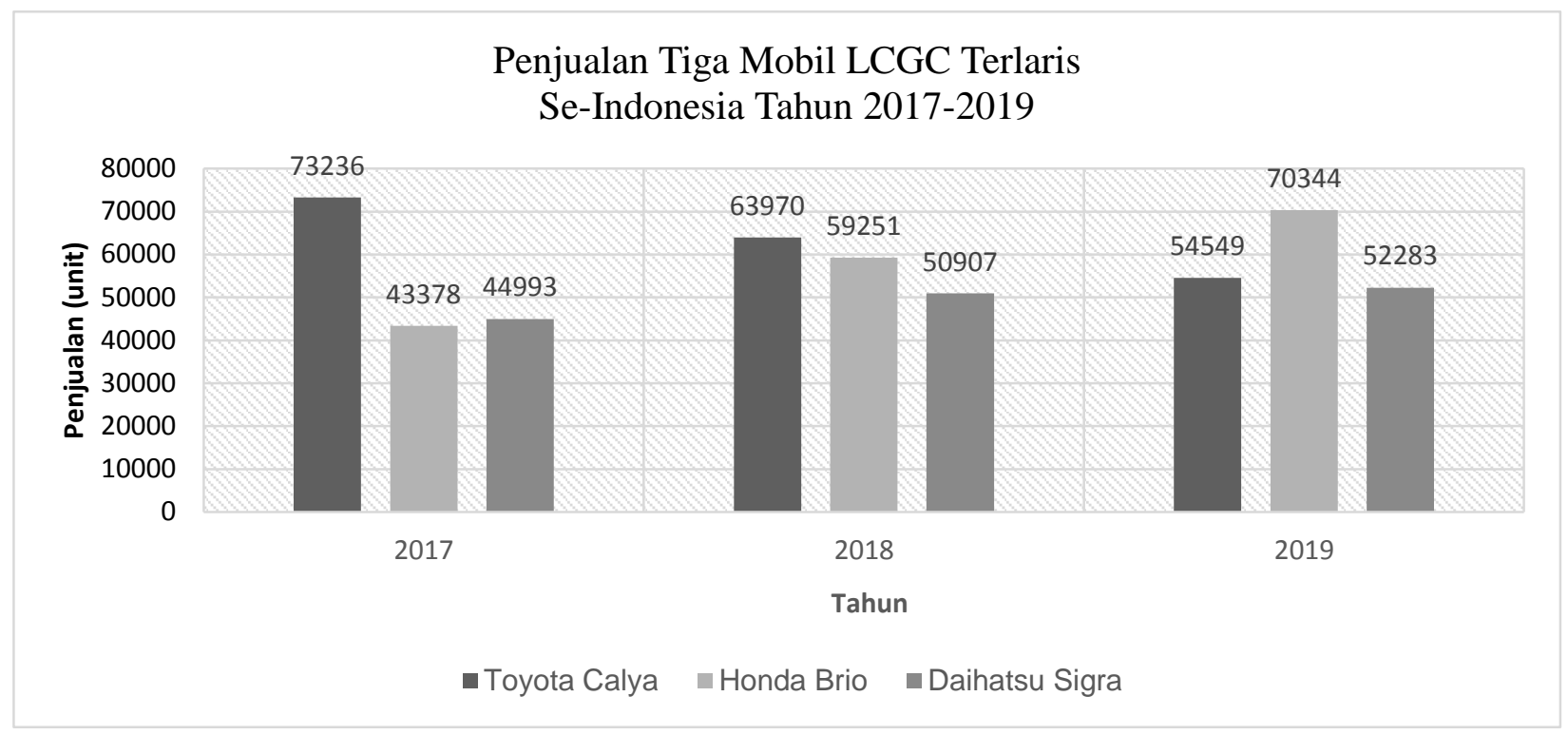

Selain fakta tersebut, berdasarkan hasil wawancara awal dengan beberapa konsumen Toyota Calya diketahui bahwa kemiripan mobil Toyota Calya dengan Daihatsu Sigra membuat mereka sulit mengenali Toyota Calya jika dilihat secara sepintas dan diketahui bahwa ketika mobil Toyota Calya ditumpangi tujuh orang dewasa, maka terkadang mengalami suspensi amblas, terlebih ketika melewati marka kejut. Perlu bagi Toyota Calya untuk menyadari hal tersebut. Persaingan untuk produk otomotif khususnya mobil LCGC semakin berkembang dan ketat. Perusahaan berlomba-lomba untuk memperkuat ekuitas merek produk mereka yang kemudian dapat meningkatan keyakinan konsumen akan keputusan pembelian.

Kesadaran merek (brand awareness) dapat meningkatkan keputusan pembelian (buying decision) karena merek tersebut akan menjadi pertimbangan minat pembelian bagi konsumen, bahkan dapat menjadi pertimbangan yang serius karena tingkat kasadaran yang kuat (Keller dalam Yulian dan Anik Lestari Andjarwati, 2018: 516).

Kota Makassar merupakan salah satu kota di Indonesia dengan daya beli kendaraan yang cukup tinggi. Jumlah kendaraan yang tercatat di Samsat Makassar mencapai 2,1 juta unit, 1,6 juta unit diantaranya adalah kendaraan roda dua (www.wartakita.id). Pertimbangan lain karena Makassar merupakan komunitas heterogen dengan berbagai budaya, kebiasaan dan tingkat ekonomi.

Sehubungan dengan itu, perlu dianalisis Brand Awareness dan pengaruhnya terhadap Buying Decision Toyota Calya di Makassar.

Berdasarkan latar belakang masalah di atas, rumusan masalah dalam penelitian ini adalah sebagai berikut:

1. Bagaimana brand awareness konsumen Toyota Calya di Makassar?

2. Bagaimana buying decision konsumen Toyota Calya di Makassar?

3. Bagaimana pengaruh brand awareness terhadap buying decision Toyota Calya di Makassar?

Dalam penelitian ini, pembelian Toyota Calya dibatasi pada pembelian tahun 2019 di PT Hadji Kalla oleh konsumen yang berdomisili di Makassar. 
Berdasarkan latar belakang dan rumusan masalah, maka tujuan penelitian ini adalah:

1. Mengetahui brand awareness konsumen Toyota Calya di Makassar.

2. Mengetahui buying decision konsumen Toyota Calya di Makassar.

3. Mengetahui pengaruh brand awareness terhadap buying decision Toyota Calya di Makassar.

\section{TINJAUAN PUSTAKA}

\subsection{Brand Awareness}

Brand awareness (kesadaran merek) merupakan kemampuan individu mengenali dan mengingat merek dari suatu kategori produk tertentu, dan merupakan dimensi utama dalam ekuitas merek (Keller dalam Juliana dan Sabrina O. Sihombing, 2019: 22).

Menurut Durianto (dalam Sukotjo, 2016: 4), daya ingat konsumen mengenai merek dari tingkat terendah sampai tingkat tertinggi ada empat, yaitu:

1. Puncak Pikiran (Top of Mind)

Top of mind adalah merek yang pertama kali diingat oleh responden atau pertama kali disebut ketika responden ditanya tentang suatu produk tertentu.

2. Pengingatan Kembali Merek (Brand Recall)

Brand recall adalah mengingat kembali merek yang dicerminkan dengan merek lain yang diingat oleh responden setelah responden menyebutkan merek yang pertama.

3. Pengenalan Merek (Brand Recognition)

Brand recognition adalah pengenalan merek yaitu tingkat kesadaran responden terhadap suatu merek diukur dengan diberikan bantuan seperti ciri-ciri suatu produk.

4. Tidak Menyadari Merek (Unaware of Brand)

Unaware of brand merupakan tingkat yang paling rendah dari piramida kesadaran merek dimana konsumen tidak menyadari akan adanya suatu merek.

Setiap kegiatan pemasaran selalu berupaya untuk memperoleh tingkat kesadaran merek yang lebih tinggi sebagai top of mind. Jika suatu merek tidak berada dalam benak konsumen, merek tersebut tidak dipertimbangkan di benak konsumen. Biasanya merek-merek yang disimpan dalam ingatan konsumen adalah merek yang disukai atau dibenci (Durianto dalam Sari dkk, 2017: 205).

Menurut Keller (dalam Winadi, 2017: 3), ada empat indikator yang dapat digunakan untuk mengetahui seberapa jauh konsumen aware terhadap sebuah merek yaitu:

1. Recall, yaitu seberapa jauh konsumen dapat mengingat ketika ditanya merek apa saja yang merek ingat. Nama merek yang sederhana, mudah diucapkan, dan memiliki arti yang jelas membuat suatu merek mudah muncul dalam ingatan konsumen.

2. Recognition, yaitu seberapa jauh konsumen dapat mengenali merek tersebut termasuk ke dalam kategori tertentu.

3. Purchase, yaitu seberapa jauh konsumen akan memasukkan suatu merek ke dalam alternatif pilihan ketika akan membeli produk/layanan.

4. Consumption, yaitu seberapa jauh konsumen konsumen dapat mengenali suatu merek ketika sedang menggunakan merek pesaing.

\subsection{Buying Decision (Keputusan Pembelian)}

Menurut Peter dan Olson (dalam Yonaliza dan Yulna Dewita Hia, 2014: 108), keputusan pembelian adalah proses pengintegrasian yang mengkombinasikan pengetahuan untuk mengevaluasi dua atau lebih perilaku alternatif dan memilih salah satu diantaranya". Sementara Shciffman dan Kanuk (dalam Sari dkk, 2017: 201) mendefinisikan bahwa keputasan pembelian 
yaitu keputusan konsumen untuk membeli atau tidak membeli produk atau jasa merupakan pilihan yang penting bagi pemasar.

Pada dasarnya terdapat dua faktor penentu yang memengaruhi keputusan pembelian konsumen yaitu kekuatan lingkungan dan faktor-faktor individual (Dharmanesa, 2017; 46). Berikut kedua faktor tersebut:

1. Kekuatan lingkungan mencakup budaya, sub budaya, kelas sosial, kelompok referensi, keluarga, faktor-faktor situasional, nilai-nilai, norma dan peranan sosial, dan variabel-variabel bauran pemasaran.

2. Faktor-faktor individual mencakup persepsi, motif, pengolahan informasi, pembelajaran, sikap dan keyakinan, kepribadian, pengalaman, konsep diri, dan gaya hidup.

Menurut Swastha dan Handoko (dalam Marolla, 2013: 3) setiap keputusan pembelian konsumen mencakup beberapa komponen, diantaranya adalah:

1. Keputusan tentang jenis produk

Pembeli akan mengambil keputusan untuk membeli suatu jenis produk ketika barang atau jasa tersebut sesuai dengan kebutuhan atau keinginannya. Dengan kata lain produk atau jasa tersebut dapat memenuhi kebutuhannya sesuai dengan apa yang diinginkannya.

2. Keputusan tentang bentuk produk

Pengambilan keputusan pembelian konsumen dipengaruhi oleh atribut-atribut yang terdapat pada produk yang akan dia beli. Dalam hal ini konsumen akan memutuskan membeli barang dengan berntuk tertentu menyangkut masalah ukurannya, kualitasnya, dan lain sebagainya.

3. Keputusan tentang merek

Pengambilan keputusan membeli suatu produk dipengaruhi oleh merek suatu produk yang akan dibelinya. Keputusan tentang merek ini bersifat subjektif tergantung dari selera dan keinginan konsumen.

4. Keputusan tentang agen penjualnya

Konsumen memutuskan untuk membeli suatu produk didasarkan atas penentuan tempat dimana dia akan membeli produk tersebut. Konsumen memutuskan membeli produk pada penyalur terdekat atau terpercaya.

5. Keputusan tentang jumlah produk

Keputusan pembelian konsumen dipengaruhi oleh jumlah unit yang akan dibeli, artinya bahwa pembeliannya bisa saja dilakukan melebihi satu unit. Konsumen akan menentukan banyaknya produk yang akan dia beli

6. Keputusan tentang waktu pembelian

Pengambilan keputusan membeli dipengaruhi oleh tentang kapan suatu produk akan dibeli oleh konsumen. Artinya bahwa pembeliannya dipengaruhi waktu dan bagaimana konsumen dalam memperoleh dan membelanjakan uang yang dimilikinya. Konsumen cenderung memutuskan membeli produk saat tersedia penawaran khusus, seperti diskon (pemotongan harga) atau cashback (uang kembali).

7. Keputusan tentang cara pembayaran

Pengambilan keputusan membeli dalam hal ini dipengaruhi oleh metode atau cara pembayaran produk yang dibeli, baik secara tunai ataupun cicilan. Dalam hal ini keputusan tersebut juga akan mempengaruhi keputusan tentang penjual atau jumlah pembeliannya.

\subsection{Hubungan Brand Awareness dengan Buying Decision}

Menurut Aaker (dalam Tajudin dan Ade Sofyan Mulazid, 2017: 24) kesadaran merek mempengaruhi rasa percaya diri pelanggan atas keputusan pembelian dengan mengurangi tingkat 
risiko yang dirasakan suatu merek yang diputuskan untuk dibeli. Kesadaran merek memainkan peranan penting dalam pengambilan keputusan konsumen mengenai pertimbangan merek mana yang akan digunakan (Macdonal, et al. dalam Tajudin dan Ade Sofyan, 2017: 24).

\subsection{Kerangka Konseptual dan Hipotesis Penelitian}

Sesuai dengan tujuan penelitian ini, yaitu untuk mengetahui brand awareness dan buying decision konsumen, serta mengetahui pengaruh brand awareness terhadap buying decision, yang mana terdiri dari satu variabel bebas dan satu variabel terikat. Menurut Macdonal (dalam Tajudin dan Ade Sofyan, 2017: 24) kesadaran merek memainkan peranan penting dalam pengambilan keputusan konsumen mengenai pertimbangan merek mana yang akan digunakan.

Pada penelitian ini, variabel brand awareness memiliki empat indikator yaitu recall, recognition, purchase, dan consumption (Keller dalam Winadi, 2017: 3), sementara variabel buying decision memiliki tujuh indikator yaitu keputusan tentang jenis produk, keputusan tentang bentuk produk, keputusan tentang merek, keputusan tentang agen penjualnya, keputusan tentang jumlah produk, keputusan tentang waktu pembelian, dan keputusan tentang cara pembayaran (Swastha dan Handoko dalam Marolla, 2013: 3).

Untuk lebih jelasnya, maka penulis menggambarkan kerangka konseptual sebagai berikut:

\section{Gambar 2}

Kerangka Konseptual

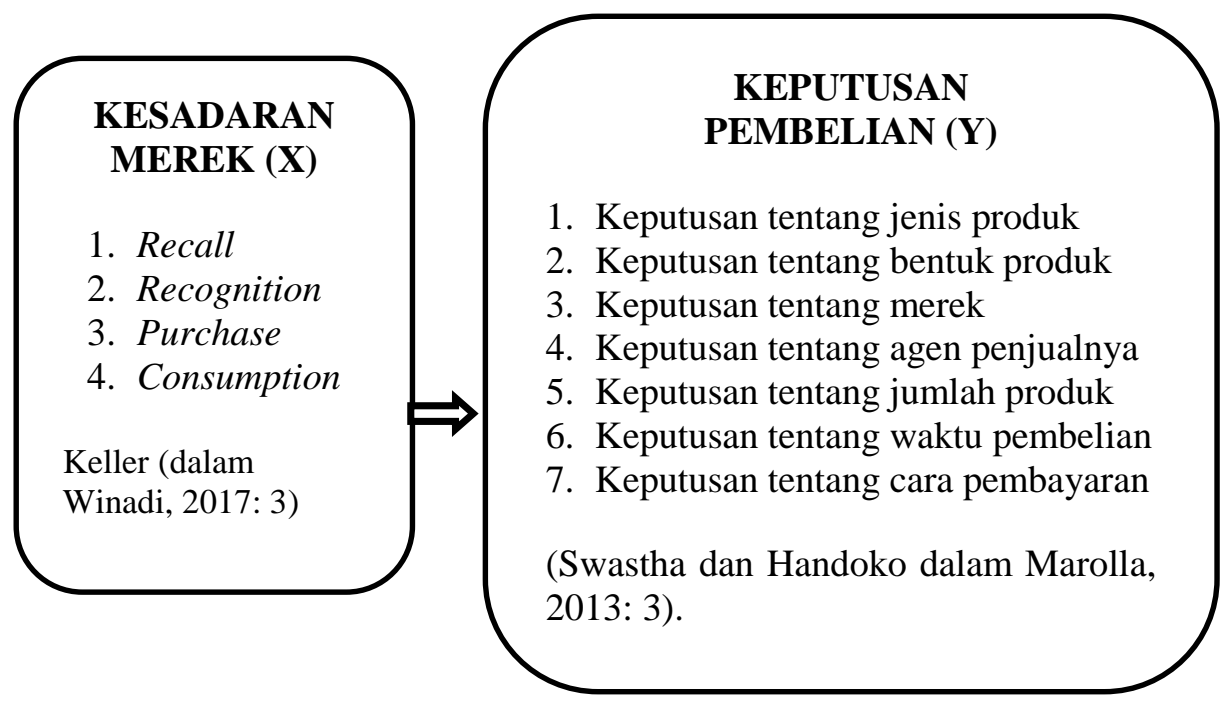

Berdasarkan kerangka konseptual, maka hipotesis penelitian ini adalah brand awareness berpengaruh positif dan signifikan terhadap buying decision Toyota Calya di Makassar.

\section{METODE PENELITIAN}

Penelitian ini dilaksanakan di kota Makassar pada bulan September 2020. Populasinya seluruh konsumen yang melakukan pembelian mobil merek Toyota Calya sepanjang tahun 2019 pada PT Hadji Kalla di Makassar yaitu sebanyak 1.117 konsumen. Jumlah sampel 92 orang. Pengumpulan data menggunakan kuesioner. Untuk tambahan informasi dilakukan pula wawancara. Metode analisis data menggunakan analisis deskriptif dan analisis regresi linier sederhana. 
Definisi operasional variabel penelitian yakni Brand awareness (kesadaran merek) adalah kemampuan untuk mengenali dan mengingat kembali merek Toyota Calya dalam benak konsumen sehingga menjadi kunci penting agar merek tersebut menjadi pertimbangan ketika memilih mobil. Buying decision (keputusan pembelian) adalah suatu sikap konsumen dalam memilih merek Toyota Calya dalam usaha memenuhi kebutuhan atau keinginan dengan cara melakukan pembelian. Hipotesis pada penelitian ini adalah brand awareness berpengaruh positif dan signifikan terhadap buying decision Toyota Calya di Makassar

\section{HASIL DAN PEMBAHASAN}

\subsection{Hasil Penelitian}

\section{Analisis Statistik Deskriptif}

a. Variabel Brand Awareness

Tanggapan responden atas pernyataan mengenai brand awareness terhadap Toyota Calya di Makassar yaitu sebagai berikut:

Tabel 1

Tanggapan Responden mengenai Brand Awareness

\begin{tabular}{|c|c|c|c|c|c|c|c|}
\hline \multirow[b]{2}{*}{ Kode } & \multirow[b]{2}{*}{ Pernyataan } & \multicolumn{5}{|c|}{ Tanggapan Responden } & \multirow{2}{*}{$\begin{array}{l}\text { Mean } \\
\text { Score }\end{array}$} \\
\hline & & $\begin{array}{l}\text { SS } \\
(5)\end{array}$ & $\begin{array}{c}S \\
(4)\end{array}$ & $\begin{array}{r}\text { KS } \\
(3)\end{array}$ & $\begin{array}{l}\text { TS } \\
(2)\end{array}$ & $\begin{array}{c}\text { STS } \\
(1)\end{array}$ & \\
\hline \multicolumn{8}{|c|}{ 1. Recall } \\
\hline $\mathrm{X}_{1}$ & $\begin{array}{l}\text { Ketika diminta menyebutkan merek mobil, } \\
\text { Anda dapat menyebutkan Toyota Calya }\end{array}$ & 51 & 39 & 2 & - & - & 4,53 \\
\hline $\mathrm{X}_{2}$ & $\begin{array}{l}\text { Menurut Anda, merek Toyota Calya mudah } \\
\text { disebut sehingga mudah diingat }\end{array}$ & 40 & 44 & 8 & - & - & 4,35 \\
\hline \multicolumn{7}{|c|}{ Rata-rata } & 4,44 \\
\hline
\end{tabular}

\section{Recognition}

Anda mengenal Toyota Calya sebagai

$\mathrm{X}_{3} \quad$ kendaraan pada kategori Low Cost Green Car $\begin{array}{llllll}43 & 30 & 19 & - & - & \text { 4,26 }\end{array}$ (mobil murah ramah lingkungan).

Anda mengenal Toyota Calya sebagai

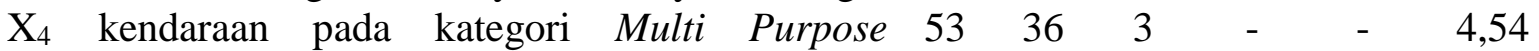

Vehicle (kendaraan multiguna).

Rata-rata

\section{Purchase}

$\mathrm{X}_{5}$ Anda membandingkan Toyota Calya dengan Anda menjadikan Toyota Calya sebagai pilihan

$\mathrm{X}_{6}$ pertama atau utama ketika ingin membeli mobil

$\begin{array}{llllll}48 & 42 & 2 & - & - & 4,50\end{array}$

$\begin{array}{llllll}33 & 44 & 15 & - & - & 4,20\end{array}$

Rata-rata

4,35

\section{Consumption}

$\mathrm{X}_{7}$ Anda dapat mengenali merek Toyota Calya 
$\begin{array}{lllllllll}\mathrm{X}_{8} & \begin{array}{l}\text { Anda dapat mengenali merek Toyota Calya } \\ \text { meski menggunakan kendaraan pesaing. }\end{array} & 44 & 31 & 17 & - & - & 4,29\end{array}$

Rata-rata

4,44

Sumber: Hasil Pengolahan Data IBM SPSS 24, September 2020

Rata-Rata Keseluruhan Item

Berdasarkan hasil rekapitulasi seluruh item pernyataan pada Tabel 4.6 diketahui bahwa nilai rata-rata keseluruhan untuk variabel brand awareness yaitu sebesar 4,44 yang termasuk ketegori sangat baik. Hal tersebut berarti bahwa responden mampu mengenali dan mengingat kembali merek Toyota Calya dalam benak mereka dengan sangat baik sehingga mempertimbangkan Toyota Calya ketika memilih mobil.

b. Variabel Buying Decision

Tanggapan responden atas pernyataan mengenai buying decision terhadap Toyota Calya di Makassar yaitu sebagai berikut:

Tabel 2

Tanggapan Responden menganai Buying Decision

\begin{tabular}{llllllll}
\hline & & \multicolumn{9}{c}{ Tanggapan Responden } & \multirow{2}{*}{ Mean } \\
\cline { 2 - 6 } Kode & Pernyataan & SS & S & KS & TS & STS & Score \\
& & $(5)$ & $(4)$ & $(3)$ & $(2)$ & $(1)$ & \\
\hline
\end{tabular}

\section{Keputusan tentang jenis produk}

Anda memutuskan membeli mobil Toyota Calya

$\mathrm{Y}_{1}$ karena keinginan sendiri untuk memiliki kendaraan yang murah dan ramah lingkungan. Anda memutuskan membeli mobil Toyota Calya

$\mathrm{Y}_{2}$ karena sesuai kebutuhan Anda, misalnya untuk mengangkut penumpang atau barang.

$$
\text { Rata-rata }
$$

$\begin{array}{lllll}40 & 37 & 15 & -\end{array}$

$\begin{array}{llllll}38 & 54 & - & - & - & 4,41\end{array}$

2. Keputusan tentang bentuk produk

$\mathrm{Y}_{3}$ Anda memutuskan membeli Toyota Calya karena menyukai ukurannya.

$\begin{array}{llllll}37 & 36 & 19 & - & - & 4,20\end{array}$

$\mathrm{Y}_{4}$ Anda memutuskan membeli Toyota Calya karena kualitas yang baik.

$$
\text { Rata-rata }
$$$$
4943 \quad-\quad-\quad-\quad 4,53
$$

\section{Keputusan tentang merk}

$\mathrm{Y}_{5}$ Anda memutuskan membeli Toyota Calya karena merek tersebut sesuai dengan selera Anda.

$\mathrm{Y}_{6}$ Anda memutuskan membeli Toyota Calya karena sesuai dengan merek yang Anda inginkan.

$$
\text { Rata-rata }
$$

$\begin{array}{llllll}38 & 54 & - & - & - & 4,41 \\ 44 & 44 & 4 & - & - & 4,43 \\ & & & & & 4,42\end{array}$

\section{Keputusan tentang agen penjualnya}

Anda memutuskan membeli Toyota Calya pada

$\mathrm{Y}_{7}$ diler (dealer) yang paling dekat dengan rumah Anda

$\begin{array}{llllll}37 & 41 \quad & - & -4,25\end{array}$


$\mathrm{Y}_{8}$ Anda memutuskan membeli Toyota Calya pada diler (dealer) yang paling Anda percayai.

$40 \quad 42 \quad-\quad 10 \quad-\quad 4,33$

Rata-rata

5. Keputusan tentang jumlah produk $\mathrm{Y}_{9} \begin{aligned} & \text { Anda memutuskan membeli satu unit Toyota } \\ & \text { Calya }\end{aligned}$

$\begin{array}{llllll}47 & 40 & 1 & 4 & - & 4,41\end{array}$

Rata-rata

\section{Keputusan tentang waktu pembelian}

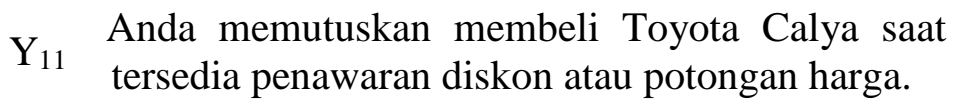

$\mathrm{Y}_{12}$ Anda memutuskan membeli Toyota Calya saat tersedia penawaran cashback atau uang kembali..

Rata-rata

$38 \quad 46-8 \quad-\quad 4,24$

$\begin{array}{llllll}39 & 39 & 11 & 3 & - & 4,24\end{array}$

\section{Keputusan tentang cara pembayaran}

$\mathrm{Y}_{14}$ Anda memutuskan membeli Toyota Calya secara $\mathrm{Y}_{14}$ cicilan atau kredit

$42 \quad 42-8 \quad-\quad 4,28$

Rata-rata

4,28

Rata-Rata Keselurahan Item

Sumber: Hasil Pengolahan Data IBM SPSS 24, September 2020

Berdasarkan hasil rekapitulasi seluruh item pernyataan pada Tabel 4.7 diketahui bahwa nilai rata-rata keseluruhan untuk variabel buying decision yaitu sebesar 4,34 yang termasuk ketegori sangat baik. Jadi dapat dikatakan bahwa responden telah menetapkan kebutuhan serta mengindentifikasi, mengevaluasi, dan memutuskan membeli Toyota Calya dalam usaha memenuhi kebutuhan atau kebutuhannya dengan sangat baik.

\subsection{Analisis Regresi Sederhana}

Analisis ini dilakukan untuk mengetahui seberapa besar pengaruh yang diberikan oleh variabel brand awareness terhadap variabel keputusan pembelian. Adapun hasil perhitungannya dapat dilihat pada tabel berikut ini.

Tabel 3

Hasil Analisis Regresi Linier Sederhana

\begin{tabular}{|c|c|c|c|c|c|c|}
\hline \multirow[b]{2}{*}{ Model } & & \multicolumn{2}{|c|}{$\begin{array}{l}\text { Unstandardized } \\
\text { Coefficients }\end{array}$} & \multirow{2}{*}{$\begin{array}{c}\text { Standardized } \\
\text { Coefficients }\end{array}$} & \multirow[b]{2}{*}{$\mathrm{t}$} & \multirow[b]{2}{*}{ Sig. } \\
\hline & & B & Std. Error & & & \\
\hline 1 & (Constant) & 2,559 & 0,419 & & 6,107 & ,000 \\
\hline & Brand awareness & ,400 & ,094 & ,409 & 4,249 & ,000 \\
\hline
\end{tabular}

Sumber: Hasil Pengolahan Data IBM SPSS 24, September 2020

Berdasarkan hasil pengolahan data yang diperoleh pada Tabel 4.11, maka dapat diperoleh persamaan regresi linear sederhana sebagai berikut:

$$
\begin{aligned}
& Y=a+b X+e \\
& Y=2,559+0,4 X
\end{aligned}
$$


Dari persamaan tersebut dapat dijelaskan bahwa konstanta sebesar 2,559, artinya jika brand awareness (X) nilainya adalah 0, maka buying decision (Y) nilainya sebesar 2,559. Koefisien regresesi variabel brand awareness sebesar 0,4 artiya setiap peningkatan satu nilai brand awareness akan diikuti oleh kenaikan 0,4 nilai buying decision.

Koefisien regresi (b) bernilai positif yang artinya terjadi pengaruh positif antara brand awareness dengan buying decision, artinya semakin meningkat brand awareness maka semakin meningkat pula buying decision.

Berdasarkan Tabel 4.11, diperoleh nilai sig. sebesar 0,000 yang lebih kecil dari 0,05 yang berberarti hipotesis penelitian diterima, sehingga dapat dikatakan bahwa brand awareness berpengaruh signifikan terhadap buying decision Toyota Calya di Makassar.

Nilai koefisien determinasi sebesar 0,167. Hal ini berarti bahwa brand awareness memiliki pengaruh sebesar $16,7 \%$ terhadap buying decision konsumen Toyota Calya di Makassar, sedangkan sisanya sebesar $83,3 \%$ dipengaruhi oleh variabel lain yang tidak diteliti pada penelitian ini.

\subsection{Pembahasan}

\section{Brand Awarenenss Konsumen Toyota Calya di Makassar}

Berdasarkan hasil analisis statistik deskriptif terhadap indikator-indikator brand awareness yaitu recall, recognition, purchase, dan consumption diketahui hasil rata-rata keseluruhan yaitu sebesar 4,44 yang termasuk dalam kategori sangat baik. Hal ini berarti brand awareness konsumen Toyota Calya di Makassar sangat baik.

Indikator dengan rata-rata tertinggi yaitu consumption, dengan nilai rata-rata 4,55. Hal tersebut menandakan konsumen Toyota Calya sangat baik dalam mengenali merek kendaraan tersebut. Sejalan dengan hasil tersebut, responden mengatakan bahwa Toyota Calya cukup mudah dikenali karena logo Burung Garuda di depan kendaraan yang khas serta ukurannya, meskipun ada kemiripan dengan kendaraan pesaing. Sementara indikator purchase dengan nilai rata-rata terendah yaitu 4,35. Nilai tersebut masih dikategorikan sangat baik, artinya konsumen mempertimbangkan dengan sangat baik merek Toyota Calya ketika ingin membeli mobil.

2. Buying Decision Konsumen Toyota Calya di Makassar

Berdasarkan hasil analisis deskriptif terhadap tujuh indikator buying decision yaitu keputusan tentang jenis produk, keputusan tentang bentuk produk, keputusan tentang merek, keputusan tentang agen penjualnya, keputusan tentang jumlah produk, keputusan tentang waktu pembelian, dan keputusan tentang cara pembayaran diperoleh nilai rata-rata sebesar 4,34. Nilai tersebut dikategorikan sangat baik, sehingga dapat diartikan bahwa buying decision konsumen Toyota Calya di Makassar sangat baik.

Diantara tujuh indikator keputusan pembelian, keputusan tentang merek meraih nilai ratarata tertinggi yaitu sebesar 4,42. Nilai tersebut dapat diartikan bahwa Toyota Calya sesuai dengan selera dan keinginan merek konsumen di Makassar. Sejalan dengan tanggapan responden saat diwawacarai, mereka menyukai merek Toyota Calya karena menginginkan merek yang terkenal. Semetara nilai rata-rata terendah pada indikator keputusan tentang waktu pembelian yaitu 4,24, nilai tersebut masih dalam kategori sangat baik.

3. Pengaruh Brand Awareness terhadap Buying Decision Toyota Calya di Makassar

Berdasarkan hasil penelitian yang dilakukan diketahui bahwa brand awareness berpengaruh positif dan signifikan terhadap buying decision Toyota Calya di Makassar. Hal ini berarti semakin meningkat brand awareness konsumen Toyota Calya di Makassar maka semakin meningkat pula buying decision-nya. Ini berarti semakin tinggi ingatan, pengenalan dan pertimbangan konsumen terhadap mobil Toyota Calya di Makassar, maka semakin tinggi (tepat) 
pula sikapnya dalam memilih jenis, bentuk, merek, agen, waktu pembelian dan cara pembayarannya terhadap Toyota Calya.

Adapun jastifikasi mengapa brand awareness berpengaruh positif dan signifikan terhadap buying decision Toyota Calya di Makassar adalah karena semakin tinggi ingatan dan pengenalan dan pertimbangan konsumen terhadap mobil Toyota Calya berarti konsumen semakin memahami karakteristik mobil tersebut dan semakin selektif (melakukan pertimbangan) untuk menentukan keputusan sehingga konsumen yang membeli mobil tersebut merasa semakin tepat pilihannya terhadap jenis, bentuk, merek, agen, waktu pembelian dan cara pembayarannya. Untuk menentukan putusan pembelian yang tepat memang harus terlebih dahulu memahami (mengenal dan mengingat) mobil tersebut. Tanpa memahami mobil tersebut, maka tentunya konsumen tidak dapat menentukan keputusan yang tepat.

Hasil penelitian ini sejalan mendukung teori yang dikemukakan oleh Aaker (dalam Tajudin dan Ade Sofyan Mulazid, 2017: 24) bahwa kesadaran merek mempengaruhi rasa percaya diri pelanggan atas keputusan pembelian dengan mengurangi tingkat risiko yang dirasakan atas suatu merek yang diputuskan untuk dibeli. Setiap kegiatan pemasaran selalu berupaya untuk memperoleh tingkat kesadaran merek yang lebih tinggi sebagai top of mind. Jika suatu merek tidak berada dalam benak konsumen, merek tersebut tidak dipertimbangkan di benak konsumen. Biasanya merek-merek yang disimpan dalam ingatan konsumen adalah merek yang disukai atau dibenci (Durianto dalam Sari dkk, 2017: 205). Menurut Dharmanesa (2017; 46). faktor-faktor individual mencakup persepsi, motif, pengolahan informasi, pembelajaran, sikap dan keyakinan, kepribadian, pengalaman, konsep diri, dan gaya hidup mempengaruhi keputusan pembelian.

.Hasil penelitian ini juga mendukung penelitian terdahulu yaitu penelitian Yonaliza dan Yulna Dewita Hia (2014) yang menunjukkan bahwa secara parsial kesadaran merek, asosiasi merek dan persepsi kaulitas berpengaruh terhadap keputusan pembelian PC Tablet Samsung Galaxy di Kota Padang. Lalu, Hakimah (2016) yang menunjukkan bahwa secara parsial masingmasing variabel kesadaran merek, persepsi kualitas, asosiasi merek, loyalitas merek berpengaruh secara signifikan terhadap keputusan pembelian. Vika Yulia Sari, Dessyta Gumanti, dan Sumarni (2017) yang menunjukkan 1) Kesadaran merek berpengaruh positif dan signifikan terhadap keputusan pembelian handphone Samsung. 2) Persepsi kualitas berpengaruh positif dan signifikan terhadap keputusan pembelian handphone Samsung. 3) Asosiasi merek berpengaruh positif dan signifikan terhadap keputusan pembelian handphone Samsung. Yanti dan Hendri Sukotjo (2016) menunjukkan bahwa variabel Kesadaran Merek, Asosiasi Merek, dan Brand Image secara parsial berpengaruh signifikan terhadap keputusan konsumen membeli air minum dalam kemasan Aqua.

\section{KESIMPULAN}

Adapun kesimpulan penelitian ini adalah:

1. Brand awarness konsumen Toyota Calya di Makassar dalam kategori sangat baik..

2. Buying decision konsumen Toyota Calya di Makassar dalam kategori sangat baik..

3. Brand awareness berpengaruh positif dan signifikan terhadap buying decision Toyota Calya di Makassar.

Sedangkan, saran-saran yang dapat diberikan untuk penelitian ini sebagai berikut:

1. perusahaan lebih memperhatikan dan berupaya mepertahankan serta meningkatkan brand awareness atau kesadaran merek konsumen terhadap Toyota Calya agar konsumen menjadikan merek tersebut sebagai pilihan utama ketika ingin membeli mobil. 
2. Sebaiknya perusahaan lebih memperhatikan dan berupaya menyebarluaskan penawaranpenawaran seperti diskon atau cashback kepada konsumen agar konsumen lebih mudah untuk mendapatkan informasi dan menetapkan waktu membeli kendaraan yang tepat.

3. Bagi peneliti selanjutnya, sebaiknya menambahkan variabel lainnya untuk melihat faktor lain yang dapat memberikan pengaruh terhadap buying decision.

\section{UCAPAN TERIMA KASIH}

Penulis mengucapkan banyak terima kasih kepada pimpinan dan karyawan PT Hadji Kalla di Makassar, para responden dan semua pihak yang telah membantu dalam kegiatan penelitian.

\section{DAFTAR PUSTAKA}

Dharmanesa, B. (2017). Manajemen pemasaran. Edisi 2, Tangerang Selatan: Universitas Terbuka.

Hakimah, E. N. (2016). Pengaruh kesadaran merek, persepsi kualitas, asosiasi merek, loyalitas merek terhadap keputusan pembelian makanan khas daerah Kediri tahu merek "POO" pada pengunjung toko pusat oleh-oleh Kota Kediri. Jurnal NUSAMBA, (Online), 1 (1). (Https://ojs.unpkediri.ac.id/index.php/manajemen/article/view/296), diakses 21 Maret 2020.

Juliana, S. (2019). Pengaruh penempatan produk dan kesadaran merek terhadap niat beli. Jurnal Manajemen dan Pemasaran Jasa, 12. (Http://dx.doi.org/10.25105/jmpj.v12i1.3702), diakses 26 April 2020.

Kotler, P., \& Kevin, L. K. (2017). Manajemen pemasaran. Edisi 12, Jilid 1, Dialihbahasakan oleh Benyamin Molan, Jakarta: PT Indeks.

Marolla, S. F.H. (2013). Gambaran komponen yang mempengaruhi keputusan membeli handphone Blackberry dan gaya hidup konsumen. Jurnal Ilmiah Mahasiswa Universitas Surabaya, (Online), 2 (1). (Https://media.neliti.com/media/publications/183986-IDgambaran-komponen-yang-mempengaruhi-kepu.pdf), diakses 20 Juli 2020

Sari, Vika Y., dkk. (2017). Pengaruh kesadaran merek, persepsi kualitas, dan asosiasi merek terhadap keputusan pembelian handphone Samsung (Studi Kasus Mahasiswa Program Studi Pendidikan Ekonomi STKIP PGRI Sumatra Barat). Jurnal of Economic and Economic Education, (Online), 5 (2). (Http://dx.doi.org/10/2202/economica.2017.5.1852), diakses 7 Juni 2020.

Sukotjo, H. (2016). Pengaruh kesadaran merek, asosiasi merek, dan brand image terhadap keputusan pembelian Aqua. Jurnal Ilmu dan Riset Manajemen, (Online), 5( 5).

Tajudin, Makhdaleva Hanura dan Ade Sofyan Mulazid. 2017. Pengaruh promosi, kepercayaan, dan kesadaran merek terhadap keputusan nasabah menggunakan produk tabungan haji (Mabrur) Bank Syariah Mandiri KCP. Sawangan Kota Depok. Jurnal Ekonomi Islam, (Online), 8 (1). (Http://journal.islamiconomic.or.id/index.php/ijei/article/view/64) diakses 26 April 2020.

Tjiptono, Fandy, \& Anastasia D. (2016). Pemasarn esensi \& aplikasi. Yogyakarta: CV Andi Offset.

Wibowo, S. F., \& Karimah, M. P. (2012). Pengaruh iklan televisi dan harga terhadap keputusan pembelian sabun Lux (Survei pada pengunjung Mega Bekasi Hypermall). JRMSI-Jurnal Riset Manajemen Sains $\quad$ Indonesia, 3 (1). (Http://journal.unj.ac.id/unj/index.php/jrmsi/article/view/771), diakses 21 Juli 2020 
Winadi, J. S. (2017). Hubungan word of mouth dengan brand awareness teh kotak. Jurnal EKomunikasi, (Onlie), 5 (1). (Https://media.neliti.com/media/publications/185778-idhubungan-word-of-mouth-dengan-brand-awar.pdf), diakses 10 September 2020.

Yonaliza, Y. D. H. (2014). Pengaruh kesadaran merek, asosiasi merek, dan persepsi kualitas terhadap keputusan pembelian pc tablet samsung Galaxy di Kota Padang. Jurnal of Economic and Economic Education, (Online), 2 (2). (Http://dx.doi.org/10.22202/economica.2014.v2.i2.223), diakses 7 Juni 2020.

Yulian, D.T., \& Anik, L.A.(2018). Pengaruh brand awareness, perceived quality, dan kelompok acuan terhadap niat beli Honda PCX 150 (Studi pada komunitas sepeda motor matic di Surabaya pusat). Prosiding Seminar Nasional Manajemen dan Bisnis ke-3. (Online). (Https://jurnal.unej.ac.id/index.php/prosiding/article/view/9209), diakses 7 Juni 2020 